\title{
The Divine Wisdom and the Divine Economy
}

PAUL T. NIMMO

\begin{abstract}
This article offers an initial exposition of the divine perfection of wisdom, and proceeds by way of attention to and development of the apostolic witness to Jesus Christ found in Scripture. The first section offers a brief reflection on method, and outlines a path of inquiry that affords primary attention to the apostolic proclamation of Jesus Christ. The second section outlines the contours of an account of the divine wisdom derived in this way. From this perspective, light is shed on the relationship between the divine wisdom and the divine acts of creation and providence. The final section briefly considers the implications of pursuing this trajectory into theology proper, that is, its possible implications for the doctrine of God.
\end{abstract}

\section{Introduction}

To venture to write on the divine wisdom is always, at best, an aporetic endeavor. Attendant at this dogmatic juncture are not only the general dangers that befall any sinful creature - even a justified sinner - who seeks to speak positively of God and of the perfections of God. Attendant 
here also are the particular risks of seeking to conceive a perfection - the divine wisdom - that Scripture so consistently portrays as being in opposition to the best of human wisdom. ${ }^{1}$

With caution in mind, this article seeks to offer an initial exposition of the divine perfection of wisdom - given the constraints of space, it can only hope to proceed by way of sketching a broad outline in brief compass. The article falls into three distinct sections. The first section offers a brief reflection on method, and outlines a way of proceeding that affords primary attention to the apostolic proclamation of Jesus Christ as it is revealed and received in Scripture. This Christocentric move involves a deliberate turning aside from the way pursued both in some recent work in Protestant dogmatics and in many traditional presentations of Christian doctrine. The second section outlines the material contours of an account of the divine wisdom derived in this way, and is ordered precisely so as to indicate the desirable centrality of the apostolic teaching of the work of Jesus Christ in conceiving this divine perfection. From this perspective, light is shed on the relationship between the divine wisdom and the divine acts of creation and providence. The final section briefly considers the implications of pursuing this trajectory into theology proper, that is, its possible implications for the doctrine of God.

\section{Method and the Divine Perfections}

[The Son] is the image of the invisible God, the firstborn of all creation.

Col. 1:15.

\footnotetext{
${ }^{1}$ And were this not enough, the particular venture of this article is undertaken in full knowledge of the excellent conference on divine wisdom (and foolishness) which took place in the University of Geneva from 23-25 May, 2013, whose proceedings have since appeared as The Wisdom and Foolishness of God, eds. Christophe Chalamet and Hans-Christoph Askani (Minneapolis, MN: Fortress Press, 2015).
} 
To begin theological reflection on the divine perfections from the perspective of the apostolic witness to Jesus Christ is to endorse a starting-point that has been deeply significant in recent endeavors in systematic theology, particularly along a certain trajectory of modern Protestant thinking. Among those who - for all their differences - have inhabited points on this trajectory are Friedrich Schleiermacher, Hermann Cremer, Karl Barth, Emil Brunner, Otto Weber, Hendrikus Berkhof, and Eberhard Jüngel, though others could also be adduced. ${ }^{2}$ At the center of the dogmatic procedure in each case is the view that the best - in fact, only - way to knowledge of God is to attend to where God has revealed Godself to us, and that means, in the incarnation of God in Jesus Christ and in the soteriological reality effected, revealed, and experienced in that divine work.

It is in Jesus Christ, as Scripture states, that there exists "the image of God" (2 Cor. 4:4). It is Jesus Christ who states that "The Father and I are one" (John 10:30), and that "Whoever has seen me has seen the Father" (John 14:9). And it is Jesus Christ, crucified, whom Paul seeks to proclaim (1 Cor. 1:23). In this spirit, then, Hermann Cremer writes, "We must therefore bind what we say about the essence of God firmly to [God's] revelation in Christ."” Or again, and with specific relevance to the attribute of wisdom in view in this article, Schleiermacher avers that

\footnotetext{
${ }^{2}$ See for example, in translation: Friedrich Schleiermacher, Christian Faith: A New Translation and Critical Edition, second edition (1830/1831), trans. Terrence N. Tice, Catherine L. Kelsey, and Edwina Lawler, ed. Catherine L. Kelsey and Terrence N. Tice, 2 vol. (Louisville, KY: Westminster John Knox Press, 2016); Hermann Cremer, The Christian Doctrine of the Divine Attributes, trans. Robert B. Price (Eugene, OR: Pickwick, 2016); Karl Barth, Church Dogmatics [hereafter $C D$ ], 4 volumes in 13 parts, edited by G. W. Bromiley and T. F. Torrance, translated by G. W. Bromiley et al. (Edinburgh: T\&T Clark, 1956-1975); Emil Brunner, Dogmatics, trans. Olive Wyon, David Cairns, and T. H. L. Parker, 3 vol. (London: Lutterworth Press, 1949-1952-1962); Otto Weber, Foundation of Dogmatics, trans. by Darrell L. Guder, 2 vol. (Grand Rapids, MI: Wm. B. Eerdmans Publishing Company, 1981-1983); Hendrikus Berkhof, Christian Faith: An Introduction to the Study of the Faith, trans. Sierd Woustra (Grand Rapids, MI: Wm. B. Eerdmans Publishing Company, 1979); Eberhard Jüngel, God as the Mystery of the World: On the Foundation of the Theology of the Crucified One in the Dispute between Theism and Atheism, trans. Darrell L. Guder (Edinburgh: T\&T Clark, 1983). That these different ventures to construe the divine perfections arrive at rather different material presentations should be immediately obvious; the point here is to emphasize the commonality of their stated points of departure rather than to claim any identity of material destination.

${ }^{3}$ Cremer, Divine Attributes, 7.
} 
when "we recognize redemption to be the actual key to understanding divine wisdom, this comprises the distinctively Christian conception of the subject."4 Two consequences follow swiftly along this trajectory of thought. First, over-vigorous distinctions between different classes of divine perfections tend to be relativized..$^{5}$ And second, the claim that there can be no aspect of God's being which is not disclosed in the revelation of God in Jesus Christ tends to be advanced. ${ }^{6}$

To commence from this latter point of orientation in pursuit of an avowedly Christocentric approach to theology - whether theology here be widely or narrowly construed - bears with it an immediate corollary, one which has relevance for the proximate inquiry into divine wisdom. This procedure broadly adjudicates that the ways of natural theology are at best redundant and at worst misleading in respect of dogmatic enquiry. It insists that the Christian God is neither a phantasm of human projection nor a postulate of human philosophy. ${ }^{7}$ In its historical exposition, the latter negation often includes the repeated rejection of the perceived influence of Hellenistic thought on

\footnotetext{
${ }^{4}$ Schleiermacher, Christian Faith, §168.2; 2:1012.

${ }^{5}$ In view here is the unhelpfully robust distribution of divine perfections between categories of absolute-relative, internal-external, ontological-economic, transcendent-immanent, and so on. As John Webster notes, "One consequence of [the] strong identity between the divine Word and the historical form which it assumes is to close the space between God absolutely considered and God relatively considered." God without Measure: Working Papers in Christian Theology, vol. 1: God and the Works of God (London-New York: Bloomsbury-T\&T Clark, 2016), 53. Webster is right on this point, even as he resists both this identity and its implications. Nevertheless, it should be recognized that many of the Christocentric presentations noted above continue to employ such distinctions heuristically for the purposes of conceiving and presenting the divine perfections: for example, Barth identifies two series of divine perfections under the rubrics of the divine love and the divine freedom, $C D$ II/ $1, \S \S 30-1$; Otto Weber proceeds in a similar way, Foundations of Dogmatics, 1:§§X.C-D; and even Cremer speaks of those "divine attributes disclosed in revelation" and those "divine attributes implicit in the concept of God, seen in light of revelation." Divine Attributes, chapters 3-4. A relativization, then, need not mean an eradication.

${ }^{6}$ Cremer, Divine Attributes, 8. Of course, to argue that there is no perfection of God that is not disclosed in revelation is not to argue either that the being of God is somehow circumscribed by or limited to revelation or that the being of God is somehow perfectly comprehended by the recipients of revelation. As Hendrikus Berkhof writes, "God's essence transcends his revelation." Berkhof, Christian Faith, 106.

${ }^{7}$ The typical bêtes noires at this point are, of course, the philosophers Ludwig Feuerbach and Immanuel Kant respectively. But it might be observed that similar or related modes of thinking seem at different times to find their way into Christian theological reflection, whether by way of an unrestrained theologia gloriae (theology of glory) or via eminentiae (way of eminence), on the one hand, or by way of an undisciplined quest for proofs of God's existence, on the other hand. Such imitations inherently harbor the potential to construe the divine wisdom in ways that can seem rather remote from Scripture.
} 
Christian theology. ${ }^{8}$ Yet one need not accept any Hellenization thesis at all to maintain the material point that natural theology does not yield an adequate way forward in conceiving the divine perfections. ${ }^{9}$ One might simply begin dogmatically with the presupposition that Christian theology has to do with the true and living God who is eternally Father, Son, and Spirit, and who is revealed definitively in time by the power of the Spirit in the person of Jesus Christ. On that basis, faithful speech of the wisdom of God might be said to be incomplete without central reference to the apostolic witness to Jesus Christ in whom that wisdom is paradigmatically revealed. It is as God accommodates Godself to the limited capacity of humanity in this person of Jesus Christ that both the ways and works of God in the world and the character and person of God in all eternity are centrally manifest. ${ }^{10}$

Despite having been a popular paradigm in much recent Protestant theology, precisely this kind of Christocentric orientation has recently received important critical scrutiny from Protestant theologians such as John Webster, Steven Duby, and Michael Allen. ${ }^{11}$ Resisting such broadly

\footnotetext{
${ }^{8}$ See, for vivid examples of this rejection, the work of Berkhof, Christian Faith, 114-8, or, in a more historical vein, of Adolf Harnack, What is Christianity?, trans. Thomas Bailey Saunders (London: Williams \& Norgate, 1904), passim.

${ }^{9}$ The Hellenization thesis has been roundly critiqued in works such as Robert Louis Wilken, The Spirit of Early Christianity (New Haven, CT: Yale University Press, 2003); Paul L. Gavrilyuk, The Suffering of the Impassible God: The Dialectics of Patristic Thought (Oxford: Oxford University Press, 2006); and Rob Lister, God is Impassible and Impassioned (Wheaton, IL: Crossway, 2012). However, the rejection of natural theology is a separate matter. For a careful defense of this position, see K. Barth, $C D$ II/1, 85-128.

${ }^{10}$ At this point, then, there is a parting of the ways with the recent dogmatic work of Katherine Sonderegger, Systematic Theology, vol. 1: The Doctrine of God (Minneapolis, MN: Fortress Press, 2015). Sonderegger sets forth an account of knowledge of God which derives its material content not only from the incarnation of God in Jesus Christ, but also from the presence of God in the cosmos. Sonderegger writes: "Almighty God moves toward His cosmos in (at least) two ways and modes, as Word made flesh, Divine Son to human nature; and as Spirit, Creator God and eternal Light, cascading down into the world, buried within and inhabiting the earth. Incarnation and creation: these are the two ways of the One God." Systematic Theology, 1:418. For Sonderegger, it is important to observe, this is not a return to natural theology, for the construal of that whole issue is rendered moot by the dissolution of its naturalistic premise (Systematic Theology, 1:118). Yet it is clear that there is here set in play another trajectory to knowledge of God than that rendered accessible on the grounds of the apostolic proclamation of Jesus Christ, and the question then arises of the sufficiency of the former and the necessity of the latter. A full engagement with Sonderegger on these points will have to await the greatly anticipated second volume of her creative and inspiring work.

${ }^{11}$ See, for example, Webster, God without Measure, vol. 1; Steven J. Duby, Divine Simplicity (London-New York: Bloomsbury-T\&T Clark, 2015); and Michael Allen, "Divine Attributes," in Christian Dogmatics: Reformed
} 
modern trajectories of thought, these thinkers have commended in their place versions of a more classical theism, drawing variously on diverse works from earlier periods in the Christian tradition - patristic, medieval, and reformational.

Reservations about the Christological orientation being pursued here have been stated with particular clarity and regularity in the work of John Webster. In his later years, his attempt to pursue "theological theology"12 included a number of essays expressing his view that the correct order and proportion of dogmatic thought should avoid "Christological maximalism." course, Webster explicitly acknowledged that "each element of Christian teaching bears some relation to Christology," 14 and also recognized that "Christology is not exhausted by the history of redemption." 15 However, he expressed concern at those theologies in which the "[e]xposition of the history of grace as the final cause of creation takes priority over contemplation of God the creator and God's act of creation."16 This sort of arrangement, Webster argues, "raises an expectation that what needs to be said about the natures of God and the creatures of God, and therefore of their relation, may be determined almost exhaustively by attending to the economy of salvation - the history of election and reconciliation in the external missions of the Son and the Holy Spirit."17

Webster expressed a catalogue of worries about such an overtly economic approach, both in dogmatic principle and in recent practice. He suggested that being absorbed by the dramatic-

Theology for the Church Catholic (Grand Rapids, MI: Baker Academic, 2016), 57-77. It would be remiss at this point not to mention my significant personal debt to John Webster- my predecessor at the University of Aberdeen and a long-standing collaborator in various enterprises for over a decade. I continue to miss greatly his wisdom, encouragement, and humor.

${ }^{12}$ See John Webster, "What Makes Theology Theological?," Journal of Analytic Theology 3 (2015): 17-28.

${ }^{13}$ Webster, God without Measure, 1:8.

${ }^{14}$ Ibid., 1:43.

${ }^{15}$ Ibid., 1:52.

${ }^{16}$ Ibid., 1:118.

${ }^{17}$ Ibid., 1:118-9. 
historical economy could render "the distinction between God and world [...] in comparative or relatively contrastive terms as a distinction within the world, one between commensurable historical agents." ${ }^{\text {18 }} \mathrm{He}$ observed that according primacy to the economy may "come to treat God and created things as paired, $[\ldots]$ constituted by their mutual relations," a feature which could become especially prominent if such an approach licensed "talk of God as some sort of magnified historical agent acting on the same plane as other such agents." ${ }^{19}$ The dominance of the "economic" was one factor in recent work which contributed to the promotion of "a soteriology in which the foundations of salvation in the will of the Lord remain inadequately articulated." 20 And while recognizing clearly the "unsubstitutability" of Jesus, he worried that this conviction could occasion "over-intensification of one indispensable element of Christology and attenuation of the way in which that element directs attention to God's inner life."21

Conversely, for Webster, soteriology is not the "rector et iudex super omnia genera doctrinarum" (ruler and judge over all other Christian doctrines), but is rather a "derivative doctrine," formally and materially downstream of the Christian doctrine of God, and thus not that doctrine from which all others arise. ${ }^{22}$ The articulation of the work of grace is thus not the starting-point of dogmatics but itself depends upon principles laid down previously in the doctrine of creation ${ }^{23}$ - and, ultimately, prior to that, in the doctrine of God. ${ }^{24}$ Questions of a material nature are here accompanied, then, by questions of order and proportion.

\footnotetext{
18 Ibid., 1:122.

${ }^{19}$ Ibid., 1:8.

${ }^{20}$ Ibid., 1:147-8.

${ }^{21}$ Ibid., 1:57.

22 Ibid., 1:144.

23 Ibid., 1:118.
}

${ }^{24}$ Ibid., 1:144. In this same connection, though for slightly different reasons, Webster makes common cause with Sonderegger, who elucidates that her theology is "neither Christomorphic nor Christocentric"; she recognizes that not to proceed in this way is to run counter to most Protestant dogmatic work over the past two centuries, but nevertheless insists that "A repeated refrain in this work must be that not all is Christology!” Ibid., 1:xvii. 
Yet perhaps the Christocentric procedure being advocated here, though clearly differing from the constructive proposal of Webster and others, need not fall foul of these manifold concerns. To begin with the apostolic witness to the incarnation, and to seek to understand the perfections of God (including the divine wisdom) from that perspective, need not mean that one identify God simply with the temporal or the historical. Such a conflation of the creaturely and the divine, or such a relativization of their difference, is not a necessary implication of a Christocentric approach. By contrast, it may be precisely the focus on salvation history in its mysterious and miraculous unfolding that preserves - rather than erodes - the radical difference between the Creator-Redeemer and the created-redeemed. Similarly, to begin with the apostolic witness to the incarnation need not mean that one rests with the merely temporal and historical in the conception and articulation of God, or that one rejects or resiles from serious dogmatic attention to the will of God as the presupposition of incarnation or to the person of God in all eternity. Indeed, it may be precisely the conviction that God is present and active in the event of the incarnation that necessitates questions concerning the being of God in eternity, the relationship between Father and Son in their unity and distinction, and the eternal will of God to be for humanity in Jesus Christ. Thus while Webster's fears may be justified in respect of certain dogmatic accounts with a Christocentric focus, they are by no means necessarily justified across all such existing accounts or possible accounts. Abusus non tollit usum - abuse does not vitiate use.

Of course, none of this need necessarily imply that the economy of God is - as Webster rightly rejects - "id quo maius cogitari nequit" (that than which nothing greater can be thought). ${ }^{25}$ But the real material question which is in view is the extent to which or the manner in which

\footnotetext{
${ }^{25}$ Webster, God without Measure, 1:8.
} 
something other can be thought than that which is revealed in the economy of God, and - if so the extent to which the articulation of that other that can be thought can be divorced or abstracted from reference to that which is revealed in the economy of God. The answer to this question will have pervasive implications, not only in terms of dogmatic material, but also in terms of dogmatic order and proportion.

This proposal that follows differs decisively from that set forth by Webster in terms of order, proportion, and material. On order, it begins with the apostolic teaching concerning Jesus Christ; on proportion, it treats lightly and tentatively of theology proper; and on material, it takes the apostolic teaching concerning the incarnation to be the decisive heuristic moment of Christian theology. ${ }^{26}$

To proceed methodologically on the basis of the revelation of God in Jesus Christ at this point also begs the question of the appropriate order of presentation to pursue. There is, after all, no necessary connection between order of method and order of presentation; yet the order of presentation does seem to be important. In much of the tradition, the presentation of the divine wisdom revealed in the economy of God begins in quite general terms, with the creation itself, and the trajectory then runs forward through the governing of creation and the restraining of sin to culminate in the wisdom of the work of salvation. ${ }^{27}$ It lies close to hand here, however, to begin with the apostolic testimony to Jesus Christ, as opposed to seeking conceptually to replicate the temporal unfolding of salvation history from eternity past to eternity future. Such an ordering seeks to be transparent from the outset in its Christocentric focus. Thereafter, a path of inquiry will be traced back to the doctrines of creation and providence, and finally - in the concluding

\footnotetext{
${ }^{26}$ A distinction might usefully be made between being led by the apostolic proclamation (in its canonical entirety) and being led by Christology. This distinction is not clear in Allen, "Divine Attributes," 64-5.

${ }^{27}$ See, for example, Richard Muller, Post-Reformation Reformed Dogmatics, vol. 3: The Divine Essence and Attributes (Grand Rapids, MI: Baker Book House, 2003), 388.
} 
section - to the doctrine of God in eternity. ${ }^{28}$

\section{Wisdom as a Divine Perfection}

\subsection{Wisdom and Jesus Christ}

Paul writes of Jesus Christ crucified, the object of his proclamation, that he is "wisdom from God, and righteousness and sanctification and redemption" (1 Cor. 1.30). Indeed - to those who are called - he is "the power of God and the wisdom of God" (1 Cor. 1:24). It is thus in the event of the incarnation and the crucifixion that the wisdom of God is revealed: "God chose what is foolish in the world to shame the wise" (1 Cor. 1:27). It should therefore not surprise that much of the tradition spoke of Jesus Christ as the Wisdom of God, even as the doctrine of appropriations counsels that such predication should not be exclusive and should leave open room to describe the Spirit similarly - as has occasionally been evinced. ${ }^{29}$

A first thing to note is that in the apostolic testimony, the divine wisdom is set in contrast to the "wisdom of the wise;" indeed, Scripture declares, this latter, all-too-human wisdom shall be destroyed (1 Cor. 1:19). Many corollaries follow this delineation. First, it is immediately clear that there is within the divine economy in general - and within human wisdom in particular - a perversion of and opposition to this divine wisdom. This is the wisdom that flowers on the soil of

\footnotetext{
${ }^{28}$ Clearly, for a full-orbed presentation of the divine wisdom, a temporal trajectory forwards would also have to be pursued: from Jesus Christ, through the doctrines of the Spirit and the church, to the eschaton. Indeed, on some accounts, this prospective trajectory might be considered at least as significant: in Scripture, Paul sets out his own purpose to be "that through the church the wisdom of God in its rich variety might now be made known to the rulers and authorities in the heavenly places" (Eph. 3:10). And Schleiermacher insists that "without reservation the proper work of divine wisdom is the spreading of redemption." Schleiermacher, Christian Faith, §168.2; 2:1013.

Nevertheless, for reasons of space it has been necessary in the context of the present article to set this important and complementary work to the side.

${ }^{29}$ Theophilus and Irenaeus were two early figures to make this association - the references can be found in J. N. D. Kelly, Early Christian Doctrines, (London: A\&C Black, fifth edition 1993), 102, 106.
} 
fallen creaturely endeavor, a wisdom marked by the sins of hubris, complacency, and error. Correspondingly, the rejection of the best of (false) human wisdom in view of the (true) wisdom of God is a consistent theme across Scripture. ${ }^{30}$ Second, however, it is also clear that there is within the divine economy in general (and within human wisdom in particular) an analogue of this divine wisdom. When Paul proclaims the good news, he confesses that he does not speak "with plausible words of wisdom" (1 Cor. 2:4); however, he insists that, "we do speak wisdom, though it is not a wisdom of this age or of the rulers of this age, who are doomed to perish" (1 Cor. 2:6). There is, then, true human wisdom to be preached and heard, a human wisdom corresponding to the divine wisdom that is, and that is revealed in, Jesus Christ. This is the wisdom, in the words of Luke, "of the righteous" (Luke 1:17), a wisdom that "that none of your opponents will be able to withstand or contradict" (Luke 21:15). ${ }^{31}$ Third, to predicate the quality of being wise to the divine being or the divine work is not in Scripture a declaration based upon a synthetic act of human judgement. It is instead a recognition and confession in faith of what is in the first instance the self-predication of God. It is by faith alone that Christians receive and recognize that it is God who is only wise (Rom. 16:27). Consequently, as Emil Brunner writes, "To call the ways of God in history 'wise" and 'rational' - does not lie in the sphere of natural judgment, based on perception and logic [...] it is 'seeing' with the eyes of faith." 32

These initial reflections remain broadly formal in tone, but they already point towards the way in which an economic trajectory of theological inquiry might proceed and towards the ambition which it inherently possesses. Crucially, they already render apparent how a line of inquiry which proceeds from the apostolic proclamation of Christ crucified need not fall foul of

\footnotetext{
${ }^{30}$ In the background of 1 Cor. 1:19 stands Isa. 29:14; among many cognate verses one might mention Job 5:123, Jer. 8:9, and 1 Cor. 3:19-20.

${ }^{31}$ The use of the term "wisdom" in respect of the divine and of the human is thus analogous - to speak of divine wisdom and of (genuine) human wisdom is not to speak of two entirely unrelated matters.

${ }^{32}$ Brunner, Dogmatics, 1:284-5.
} 
the dangers which Webster articulated. The clear and uni-directional distinction between divine wisdom and human wisdom, and the utter dependability of the latter upon the former as presented here, together indicate resolutely the irreversible nature of the relationship between God and human beings and an explicit rejection of any sense of sapiential "pairing." Otto Weber carefully articulates this ontological distance between God and humanity: "The incarnation is not [God's] transformation into human being. [...] His entry into the realm of our knowledge does not make him subject to reason. His entry into our history does not coordinate him with our history. He is 'God towards us' (Deus erga nos), but not 'God according to us' (Deus secundum nos).,"33

To proceed Christocentrically need not mean rendering God and humanity on the same plane.

Materially, the wisdom of God - according to the apostolic testimony - reveals itself definitively in the life and work of Jesus Christ, a life lived in an impoverished country under foreign occupation, inexorably leading towards the horror of legal injustice and military execution, and culminating in the glorious and unexpected resurrection. The purpose of this revelation, as the First Letter to the Corinthians indicates, is the salvation of those who believe through the "foolishness" of the proclamation of Paul and his co-workers in the Gospel (1 Cor. 1:21).

To speak of the divine wisdom among the divine perfections at this juncture is thus to speak of an attribute that is defined in a fashion that is (a) positive, (b) particular, and (c) purposive.

First, divine wisdom is not a quality that is identified privatively, as - for example -

\footnotetext{
${ }^{33}$ Weber, Foundation of Dogmatics, 1:401.
} 
certain traditional perfections such as immutability or impassibility might be considered to be.

There is thus no definition of divine wisdom that proceeds along a via negativa (way of negation) in opposition to any infelicitous or imperfect quality of creation as such. Instead, it is defined substantively, with reference to the positive content of salvation history rather than any absence, indeterminacy, or deficiency.

Second, divine wisdom is not a quality that is identified quantitatively, even by way of reckoning it to be infinite, as - for example - traditional qualities such as omnipotence and omniscience might be considered to be. There is thus no definition of divine wisdom as comparatively or even maximally greater than any quality of creation. Instead, it is defined concretely, with reference to the specific content of the Gospel rather than an unspecified compass, however impressive or unlimited or superior. ${ }^{34}$

And third, and beyond this, divine wisdom is not a quality that is identified capriciously or contingently. Thus there is no definition of divine wisdom which merely pertains to the maintenance of a status quo of a merely arbitrary nature without end or goal in sight. Instead, it is defined teleologically, with reference to the willed decree and execution of the plan of salvation in the person of Jesus Christ and its goal in the salvation of human beings. ${ }^{35}$

\footnotetext{
${ }^{34}$ Brunner writes in a way which may seem to contradict this view when he suggests that "this Divine Wisdom is the Power of God in its absolutely unlimited spiritual creativity." Dogmatics, 1:283. But this kind of conception of unlimitedness in respect of the divine attributes may not always be helpful. On the one hand, it risks pairing Creator and creation in an unhelpful way (just as Webster fears), in so far as unlimitedness - or infinity - is taken merely to be the opposite of limitation - or finitude. On the other hand, it risks rendering the divine wisdom a brute and absolute quality that lacks specificity or purpose.

${ }^{35}$ At this point one might critically demur to the contention of Katherine Sonderegger that God might be considered to be Love without object, Systematic Theology, 1:481. The parallel contention here would advocate that God might be considered to be Wise without object - simply by virtue of existing. Sonderegger's contention concerning love is - among other motivations - directed by an over-riding concern for the unity of God, and a strong desire to avoid inappropriate social construals of the Trinity. That desire and concern are shared here. However, the basic notion that Love or Wisdom might be a quality without object may run the danger of straining the acceptable
} 
This identification leads to one of the difficult issues concerning the divine wisdom. If God is wise, and eternally so, and God's wisdom is revealed in Jesus Christ, and fully so, then is the wisdom of God fully revealed? To cut to the point: is there any sense in which the wisdom of God is and remains hidden? The question is posed in its own way by Paul - "O the depth of the riches and wisdom and knowledge of God! How unsearchable are his judgments and how inscrutable his ways!" (Rom. 11:33) - as well as by Job's friend Zophar: "Can you find out the deep things of God? Can you find out the limit of the Almighty?" (Job 11:7). In the tradition of Christian thought there has arisen at points a distinction between a revealed wisdom of God and a hidden or inscrutable wisdom of God, famously in reformational approaches to the doctrine of election. ${ }^{36}$

There are three things to be affirmed here on the basis of a Christocentric perspective.

First, to affirm that the wisdom of God is unsearchable and beyond finding out indicates that there is no way from the stirrings of the human intellect to the truths of the divine being. This is simply the corollary of the view that divine wisdom is known only by virtue of the divine selfpredication that is disclosed in divine revelation. ${ }^{37}$ Second, on the basis of revelation, it must be posited that God fully reveals Godself, without reserve: there is no hidden aspect or dimension of the divine being that is undisclosed, no way to "get behind the back of Jesus to the eternal Son of

formal bounds of analogy towards equivocity, and to risk a Trinitarian monism. More would evidently need to be said at this juncture.

${ }^{36}$ See, paradigmatically, Martin Luther, "The Bondage of the Will," in Luther's Works, vol. 33: Career of the Reformer III, ed. Philip S. Watson, general editor Helmut T. Lehmann (Philadelphia, PA: Fortress Press, 1957), 13844: "Diatribe, however, deceives herself in her ignorance by not making any distinction between God preached and God hidden, that is, between the Word of God and God himself [...]. Thus [God] does not will the death of a sinner, according to his word; but he wills it according to that inscrutable will of his [...]. It is enough to know simply that there is a certain inscrutable will in God" (140).

${ }^{37}$ Barth offers the following comment on Rom. 11:33, the verse referenced above: "The aim is to prevent them

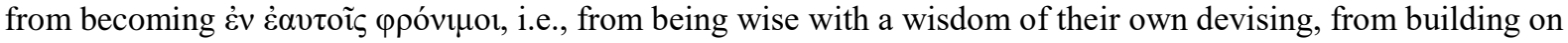
their own wisdom and in that way grounding themselves in themselves." $C D$ II/2, 299. 
God." ${ }^{38}$ It is God alone who can reveal God; but it is God (alone) who does reveal God - there is no hidden will of God that God keeps to Godself as if human beings were to be excluded from access to it. The implication of these first two affirmations, then, is an affirmation that there is a dialectic of veiling and unveiling in revelation. ${ }^{39}$ And third, all this does not mean that God and the divine wisdom are in any sense ever comprehended by human beings. The subjective correlate to the objective event of revelation - by the power of the Spirit - is faith: hence Brunner's words, "this wisdom is only accessible to faith." 40

The result is that while full understanding of the divine wisdom may always lie behind them, human beings in their engraced wisdom can truly apprehend God's wisdom, as God condescends and accommodates to their weak and corrupted state in revelation. ${ }^{41}$ The parables of Jesus serve in exemplary fashion here: true knowledge of God's Kingdom continues to exceed and overwhelm human thought; nevertheless, the parables truly display and set forth the character of the Kingdom of God. Correspondingly, all human reference to the divine wisdom - as to God at all - must involve a faithful interweaving of sincere humility and emboldened confidence. ${ }^{42}$

That the divine wisdom not only culminates in the crucifixion of Jesus but is also implicated in the other dimensions of the incarnation - his teaching and ministry on the one hand,

\footnotetext{
38 Thomas F. Torrance, "The Place of Christology in Biblical and Dogmatic Theology," in Theology in Reconstruction (London: SCM Press, 1965), 130.

${ }^{39}$ The understanding of this dialectic is developed and discussed at length by K. Barth, CD II/1, 234-6. Paul writes, "the mystery that was kept secret for long ages [...] is now disclosed [...] and [...] made known to all the Gentiles, according to the command of the eternal God." Rom. 16:25-6.

${ }^{40}$ Brunner, Dogmatics, 1:284.

41 The distinction between "comprehending" and "apprehending" is crucial here: the former suggests an ability for human understanding to encompass God and to know all there is to know without limits; the latter indicates a situation in which a true perception of or participation in the divine wisdom is received, without any sense of God's limits being approached or God's pre-eminence being threatened.

${ }^{42}$ This maps on to one of Barth's most luminous recurring insights: "As theologians, we ought to speak of God. But we are humans and as such cannot speak of God. We ought to do both, to know the 'ought' and the 'not able to,' and precisely in this way give God the glory," in The Word of God and Theology, trans. Amy Marga (London-New York: Continuum-T\&T Clark, 2011), 177 (italics original).
} 
his resurrection and ascension on the other hand - is evident from the Gospel narratives.

Luke explicitly describes the child Jesus as "filled with wisdom" (Luke 2:40) and subsequently as "increasing in wisdom" (Luke 2:52). Small wonder that those who later hear him teach in the synagogue ask "What is this wisdom that has been given to him?" (Mark 6:2). It is clear that Jesus possesses the human analogue to the divine wisdom, being the recipient of knowledge from the Father (Matt. 11:25-7) and proclaiming himself correspondingly to be greater than Solomon (Luke 11:31). His parables, already mentioned above, often treat of wisdom thematically, represent a paradigmatic performance both of the divine wisdom accommodating itself to human beings, and of the true human wisdom that corresponds to the divine wisdom. ${ }^{43}$

Yet that the telos of this wise teacher's life is never in doubt should be immediately apparent from Jesus' repeated foretelling of the cross - in all its shame and scandal - as his ultimate destination (Mark 8:31, 9:31, 10:33-4). This unerring consistency of the presence and the purpose of the divine wisdom through the life of Jesus should signal the end of any account of the crucifixion as accident or caprice. At the same time, this consistency should not beguile any theologian from failing to attend directly to the inherent and unintuitable disruptiveness that the cross represents as the earthly telos of the life of Jesus - it remains a perpetual theological temptation to overlook or underplay the unimaginable scandal and disruption (and transformation) that it represents for the religious mind and for the undeserving creation.

Yet the divine wisdom has greater compass than the crucifixion of Jesus Christ. Each foretelling of the cross noted above also prophetically announces the resurrection. And it is a failure to understand that the telos of the crucifixion lies in the resurrection that leads to Jesus

\footnotetext{
${ }^{43}$ For more on those parables which thematize wisdom, see Arland J. Hultgren, The Parables of Jesus: A Commentary (Grand Rapids, MI: Wm. B. Eerdmans Publishing Company, 2002), 129-79.
} 
sharply rebuking the disciples on the road to Emmaus - “Oh, how foolish you are [...]!” (Luke 24:25). For if Jesus Christ is not raised from the dead, then not only is the apostolic proclamation in vain (1 Cor. 15:14), but also the very wisdom of God in its foolishness has failed in its purpose.

The apostolic proclamation of the salvation achieved in Jesus Christ thus points to the specific, focused, and enacted wisdom of God. And to recognize this is to insist that the victory of the divine wisdom over human wisdom is not an intellectual victory - or at least not an intellectual victory alone. The victory of divine wisdom is the victory not of a disembodied and impersonal divine principle but of an incarnate and personal divine agent - Jesus Christ (1 Thess. 5:9-10). And the destruction of (false) human wisdom is not independent of the destruction of the possessor of that wisdom - the sinful creature who stands in opposition to and alienation from God and who is disappointed by the divine wisdom (Matt. 11:19), or - in Paul's words - the "wretched" human being in a "body of death" (Rom. 7:24).

The "new creation" (2 Cor. 5:17) that is the result of the divine irruption into history in Jesus Christ is the new creation of God who recognizes, receives, and embraces the divine wisdom as true human wisdom, and is able even to enact it. The practical consequences of this salvific wisdom of God are given material contour and color in the repeated references in the Gospel to the recalibration of human attitudes and expectations - in terms of measuring success, of ordering society, of serving faithfully, and of conceiving God. The Magnificat (Luke 1:51-3) and the beatitudes (Matt. 5:3-11) are headline articulations of this message, while the personal consequences of the divine wisdom for Christian conduct are elegantly and concisely treated in James (3:13-18). In each case, there is an indication of the radical and creative transformation of 
understanding initiated in the minds of those who encounter the divine wisdom. ${ }^{44}$ And this remains true even as, in the present age, such true creaturely wisdom continues to be harassed and haunted by the false creaturely wisdom which co-exists with it. The terrain of wisdom continues to be the ground of spiritual conflict, then and now.

\subsection{Wisdom, Creation, and Providence}

The wisdom of God is principally revealed in the divine act of reconciliation, but it is not exhausted by it. As Karl Barth notes, "in the Bible, [the wisdom of God] is defined as a wisdom which creates, maintains and rules the world and therefore as the proper instrument of divine providence. ${ }^{45}$ As the dogmatic focus of attention shifts from incarnation to creation and providence, there occurs a transition from the inner circle to the outer circle of the divine wisdom. In this movement, however, it is important to recognize that the domain of reconciliation is not left behind. For Schleiermacher, indeed, the divine wisdom is precisely defined as "the principle that orders and determines the world for the divine self-communication that is carried out in redemption." ${ }^{46}$ The wisdom in view here is thus oriented primarily towards the event of reconciliation, yet has clear implications for the order of the world. It is thus through the lens of salvation that creation and providence must be considered and construed.

This has implications for how the appropriate theological relationship of

\footnotetext{
${ }^{44}$ The reflections throughout this section are indebted to the wisdom found in David F. Ford, Christian Wisdom: Desiring God and Learning in Love (Cambridge: Cambridge University Press, 2007), especially chapters 1, 5 , and 7.

${ }^{45} \mathrm{~K}$. Barth, $C D \mathrm{II} / 2,427$.

${ }^{46}$ Schleiermacher, Christian Faith, §168.thesis; 2:1010. It should be noted that Barth's charge that this involves a "separation between the divine self-communication and a special principle ordering and fashioning the world to that end is untenable" (CD II/1, 432), is itself untenable: Schleiermacher himself declares on the following page that divine wisdom is "thought to be nothing other than Supreme Being in its absolute, not compound but simple, and originally complete self-presentation and communication." Schleiermacher, Christian Faith, §168.1; 2:1011.
} 
creation/providence and reconciliation should be conceived. One traditional trope for speaking about the activity of God in reconciliation is that it is "fitting" of God to redeem humanity by way of incarnation and crucifixion - "fitting," on the basis of who God is, and, more specifically, who God is in creation and providence. ${ }^{47}$ Yet the method here proposes intentionally to invert the direction of this relationship. The starting-point for adjudicating fittingness, according to this account, can only be the revelation of Jesus Christ. And this means that rather than declaring that it is the work of the incarnation that is "fitting" for God the Creator, it might be more appropriate to declare that it is the work of creation and providence that is "fitting" for God the Reconciler. In other words, God's wisdom in creation and providence is oriented to and circumscribed by the divinely enacted event of reconciliation, rather than the other way around. The order of nature is indeed ministerial to the order of grace, in a reversal of the conception advanced by Webster.

This contention bears with it three immediate consequences. First, it indicates that the wisdom which is relevant in considering the economy of God is not some principle internal to or immanent within the creation. The divine wisdom is nowhere to be identified with creaturely development or process, and there is no immanent or indwelling divine principle akin to the Stoic logos. As Job clearly attests, there is no wisdom simply to be found within creation (Job 28:1228). Second, then, and as before, it is clear that the wisdom of God as it pertains to creation is no more accessible to us than the wisdom of reconciliation. Rather, as the writer of Proverbs indicates, "the Lord gives wisdom; from His mouth come knowledge and understanding" (Prov. 2:6). Or again, as Jesus Christ prays to the Father, "you have hidden these things from the wise and the intelligent and have revealed them to infants" (Matt. 11:25). Brunner correspondingly observes that the emphasis of Scripture in this matter is on "that which

\footnotetext{
${ }^{47}$ Cf. Thomas Aquinas, Summa Theologica, trans. by the Fathers of the English Dominican Province (Notre Dame, IN: Christian Classics, 1981), IIIa, q. 1.
} 
transcends all our thinking, the Wisdom of the Works of Creation which can never be fathomed nor penetrated by us. ${ }^{48}$ Third, it indicates that creation and providence can never be considered without reference to their telos in redemption. There is no creation or creature in the abstract, as if there were a divine plan that did not from the first involve the enactment of redemption in Jesus Christ. Consequently - as Brunner again writes - it is from the cross alone that "we can also perceive the same law at work at other points in the history of redemption." 49

Thinking along this trajectory may harbor promise for alleviating some of the tension in recent conversations around apocalyptic theology concerning the level of continuity or discontinuity between the old covenant and the new covenant. A debate has flourished between those who seek to emphasize the connectedness of the unfolding of salvation history before and after Jesus Christ, and those who seek to emphasize the novelty and disjunction of the incarnation. ${ }^{50}$ It may be that viewing the matter against the background of reading creation and providence through reconciliation allows for the terms of this debate to be lightly recast. On the one hand, the severe dislocation caused by the entry of God into time and creation in the particular mode of incarnation may be preserved; on the other hand, understanding the previous history of God with the world (both general and covenantal) as a backdrop to and preparation for precisely this foreground may allow for the appropriate unity to be safeguarded. Materially considered, the divine wisdom - in the Christocentric and staurocentric articulation set forth in this article - may offer a way of construing this unity more deeply, with a greater degree of

\footnotetext{
${ }^{48}$ Brunner, Dogmatics, I:283.

${ }^{49}$ Ibid., I:284.

${ }^{50}$ For an outline of some of the pertinent literature, see John Anthony Dunne, "Suffering and Covenantal Hope in Galatians: A Critique of the 'Apocalyptic Reading' and its Proponents," Scottish Journal of Theology 68, no. 1 (February 2015): 1-15.
} 
complexity. ${ }^{51}$

This way of proceeding sheds additional light on some of the significant passages in Scripture which testify to the particular role of the wisdom of God in creation/providence. Among many passages, one might cite the personification of the wisdom of God found in Proverbs:

When he established the heavens, I was there, when he drew a circle on the face of the deep, when he made firm the skies above, when he established the fountains of the deep, when he assigned to the sea its limit, so that the waters might not transgress his command, when he marked out the foundations of the earth, then I was beside him, like a master worker. (Prov. 8:27-30) $)^{52}$

The wisdom of God is truly not a late entry on the temporal scene in crucifixion: according to this passage, its origins lie back beyond providence and creation to the eternal life and the eternal counsel of God. This would link clearly with Paul's claim that God's wisdom is "secret and hidden, $[\ldots]$ decreed before the ages" - but here, it is important to note, the passage continues immediately and purposefully - "for our glory” (1 Cor. 2:7). Far from confirming Webster's fears that an approach centered on the economy might fail to articulate the eternal foundations of reconciliation in the eternity of God, the trajectory followed here from crucifixion through

\footnotetext{
${ }^{51}$ In this way, a Christocentric conception of the divine wisdom could be seen as the richer and deeper backdrop to the theme of suffering, which Dunne helpfully highlights as being able to secure the unity of the apocalyptic and covenantal views of Galatians; "Suffering and Covenantal Hope in Galatians," 9-14.

${ }^{52}$ See, similarly, Prov. 3:19-20: "The LORD by wisdom founded the earth; by understanding he established the heavens; by his knowledge the deeps broke open, and the clouds drop down the dew;" or Jer. 10:12: "It is [the LORD] who made the earth by his power, who established the world by his wisdom, and by his understanding stretched out the heavens."
} 
providence and creation leads naturally to considering their basis in the eternal will of God.

Correspondingly, it is no wonder that there is a long-standing Christian move to read the characterization of Wisdom in Proverbs to refer to the eternal Son of God, as both sides did though to rather different ends - in the Arian controversy. But the desire to conceive the Wisdom of God here in a directly Christocentric manner suggests that in treating of creation and providence the second person of the Trinity cannot be conceived as a logos in abstraction absent reference to the incarnation and crucifixion. Rather, as Schleiermacher writes of the divine wisdom, "we are $[\ldots]$ able to make the entire divine ordering of the world within this domain intelligible only in reference to God's revelation in Christ and in the Holy Spirit." ${ }^{, 53}$ Here again, then, the wisdom of God is seen from the beginning of creation and providence never to be without its soteriological purpose, effected in the incarnation and crucifixion of God in Jesus Christ.

This implies that even as theology concerns itself with the event of the Fall, that most irrational and meonic locus of dogmatic enquiry, the divine wisdom is not absent. Clearly, great complexity (and dogmatic peril) accompanies any attempt to understand the relationship between the Fall and the divine wisdom. However, the fact that the world does not know God through its creaturely wisdom, according to Paul, is the case precisely "in the wisdom of God" (1 Cor. 1:21); indeed, Paul writes in Romans, "God has imprisoned all in disobedience so that he may be merciful to all” (Rom. 11:32). However difficult such texts are to read, theologically and pastorally, such biblical discourse concerning sin and Fall seldom seems to be remote from an over-arching narrative of salvific purpose on the part of God. In any reading of the (prophetic and) apostolic proclamation which is attentive to the canon, there is little evidence of sin being

\footnotetext{
${ }^{53}$ Schleiermacher, Christian Faith, §168.2; 2:1012.
} 
construed in an abstract sense. Nor, again on a canonical reading, is there much evidence of sin being related to a Law of God which is conceived independently of salvation. By contrast, the force of passages such as those quoted above is to render the tragic and horrendous realities of sin and Fall noetically and ontically conceivable only in light of the incarnation of Jesus Christ and of the salvific plan willed eternally and enacted temporally in him.

\section{Conclusion}

This article has sought to outline a theological way of proceeding in respect of the divine wisdom that differs from some contemporary approaches. It foregrounds the apostolic proclamation of the Gospel and pursues this Christocentric approach vigorously, from the incarnation through providence and creation to the eternal election of God. And it seeks studiously to avoid the kind of pitfalls which may be thought to have surfaced in certain previous attempts to follow such a line of enquiry, thus charting an alternative way forward than that set out by Webster.

The trajectory followed leads here, finally, to an exploration of the wisdom of God in respect of the eternal being of God. ${ }^{54}$ Again, far from a Christocentric trajectory necessarily attenuating attention to the eternal life of God, as Webster fears, consideration of its contours falls naturally within the purview of this method here - if by way of conclusion rather than at the outset.

Barth offers a particularly clear and concise articulation of the rootedness of the divine

\footnotetext{
${ }^{54}$ Weber also indicates that the concept of the wisdom of God refers to the "decree" of God, and thus to predestination, which is to be understood in turn as election in Christ, Foundations of Dogmatics, 1:437. However, Weber does not thematize the divine wisdom further, and thus remains susceptible to the criticism of Webster concerning a lack of attentiveness to the divine being at this point. In what follows in this article, however, attention is directed precisely to this matter.
} 
salvific purpose in the eternal will and wisdom of God: "God is wise in so far as His whole activity, as willed by Him, is also thought out by Him, and thought out by Him from the very outset with correctness and completeness, so that it is an intelligent and to that extent a reliable and liberating activity." 55

But if the incarnation of God and the crucifixion of Jesus Christ are part of this willed and elected activity of God from the beginning, the question arises of the extent to which God - or indeed the divine wisdom - can be conceived without it, without a move to abstract (whether speculatively or transcendentally) from the witness of Scripture. To put the question in a somewhat provocative form: how deep does the cross go in the identity of God? ${ }^{56}$

This is vexed theological terrain, particularly in modern Protestantism, and particularly in light of the unspeakable evils in the world in recent decades and in present times. In so far as such matters arose in the classical tradition, to speak of incarnation and crucifixion as the wisdom of God demanded that the freedom and grace of God be recognized as the necessary context of the eternal determination of that wisdom. And that in turn implied an ontic distinction - however small - between who God is and what God does, without which salvation would seem to become necessary and the grace of the Gospel would seem to become graceless.

Yet to seek to isolate some dimension or existence of the divine life from the events of the divine economy runs in a direction directly counter to the trajectory adopted in this article. Here, the effort has been made to see the divine wisdom revealed in Jesus Christ as a full disclosure of

\footnotetext{
${ }^{55}$ Barth, $C D$ II/2, 425-6 (emphasis added).

56 To ask this specific question moves the issue beyond the question of "incarnation anyway?" - on which see the excellent book by Edwin Chr. van Driel, Incarnation Anyway: Arguments for Supralapsarian Christology (New York: Oxford University Press, 2008). First, and obviously, at stake here is the horror and antagonism of crucifixion and not simply the humility and kenosis of incarnation. But second, in view here is not so much - to use the awkward and infelicitous yet common terms - an economic issue ("would God have become incarnate in time without sin?") but an immanent issue ("where is the cross in the life of God?").
} 
the being of God and not merely as a fitting correspondence to the being of God. This means not only to embrace Barth's view that "the order of His wisdom is that in Himself and in all His works He is gracious and merciful," ${ }^{57}$ but also to suggest that the wisdom in view both in the divine being as such and in the divine works is the same - Jesus Christ.

To seek to proceed in this way is once again to reverse the direction of the way that the logic of "fittingness" is deployed. It is not so much to contend that the incarnation and the crucifixion is a "fitting" act of God in light of who God is - though that in itself clearly remains in one sense true. It is instead to contend that, in light of the incarnation and the crucifixion, it is fitting for human beings to conceive of the eternity of God in this way - to conceive of God as always and eternally wise, certainly, but of that Wisdom itself as never not being oriented to the cross. In this way, it is revealed in Jesus Christ that God is the "always already saving God." 58

This is precisely not to deny ascribing grace and freedom to God or to the wisdom of God, for clearly Scripture indicates that these divine perfections are relevant both to the works and to the person of God. It is rather to seek to hold together questions of freedom and mercy, of act and identity, in a more complex way than is often attempted, and at the same time to be far more explicitly cognizant of the limits of human thinking about the eternal ways of God. It is precisely here that further dogmatic work may be desirable, with a view to avoid forcing human conceptions of God and of God's perfections onto a Procrustean bed of human making which treats freedom and necessity as binary opposites. ${ }^{59}$

\footnotetext{
${ }^{57}$ Barth, $C D$ II $/ 2,425$.

${ }^{58} \mathrm{I}$ am indebted to Janet Martin Soskice for this evocative and memorable phrase, though in recording this debt, I do not dare to assume what she might make of the interpretation of it ventured here.

${ }^{59}$ For a recent and considered treatment of this matter with reference to Bulgakov, Barth, and Balthasar, see Brandon Gallaher, Freedom and Necessity in Modern Trinitarian Theology (Oxford: Oxford University Press, 2016).
} 
In this way, it might become possible to accept the radical notion that to speak of the wisdom of God as it is revealed in the death, life, and resurrection of Jesus Christ is to speak truly not only of the very economy of God but of the very essence of God - that without which God cannot be faithfully conceived or proclaimed. The apostolic proclamation relates, after all, that it is in Jesus Christ that there "are hidden all the treasures of wisdom and knowledge" (Col. 2:3). ${ }^{60}$

It might be observed in passing that it was once thought preposterous and inappropriate to consider a begetting of a son which had never not taken place. Theology is not driven by human logic.

${ }^{60} \mathrm{I}$ am warmly grateful for the constructive comments and insightful questions of a range of people in respect of the material articulated in this paper - John Behr, Christophe Chalamet, Paul Dafydd Jones, Tom Greggs, Friedrich Lohmann, Christoph Schwöbel, Janet Soskice, and (especially) Phil Ziegler. 